\title{
THERMODYNAMIC PROPERTIES OF WHITE BEAN GRAINS FOR DIFFERENT EQUILIBRIUM WATER CONTENTS
}

\author{
Renata C. Campos ${ }^{1 *}$, Paulo C. Corrêa1, Úrsula R. Zaidan², \\ Iasmine R. Zaidan ${ }^{3}$, Rildo Araújo Leite ${ }^{4}$
}

${ }^{1 *}$ Corresponding author. Federal University of Vicosa, Vicosa Campus/ Minas Gerais - MG, Brazil.

Email: renata@ufv.br| ORCID: https://orcid.org/0000-0002-5419-5064

\section{KEYWORDS}

hygroscopic balance, isosteric heat, enthalpy, entropy, Gibbs free energy.

\begin{abstract}
In drying processes and in the storage of agricultural products, the study of thermodynamic properties is indispensable in the search for solutions to issues of stability and optimization of the conditions of agro-industrial processes. The aim of this work was to determine hygroscopic equilibrium isotherms and study the thermodynamic properties of white bean grains submitted to different equilibrium temperatures and relative humidity levels. Phaseolus vulgaris L. grains were used, with an initial water content of 0.142 (dry basis), temperature variations ranging between 18 and $50{ }^{\circ} \mathrm{C}$, and relative humidity between $19 \%$ and $78 \%$. Fifteen mathematical models were tested to determine the hygroscopic equilibrium isotherms, and the Sigma model was the one that best suited the experimental data. The thermodynamic properties of the beans were determined from Sigma-Copace model. The integral isosteric heat of desorption and the differential entropy increased with the reduction of the water content, and the phenomenon of water desorption of white bean grains was a non-spontaneous process controlled by enthalpy.
\end{abstract}

\section{INTRODUCTION}

Legumes are food items of high nutritional value; among them, the common bean (Phaseolus vulgaris L.) stands out as an excellent source of protein and is an integral part of the diet of a large majority of the Brazilian population (Brigide et al., 2014; Barros \& Prudencio, 2016). Brazil is the third largest producer of beans in the world, with 3.02 million tons produced in the three crops of 2018/19, according to an estimate by Companhia Nacional de Abastecimento (CONAB), the "colors" class being the one with the highest production, followed by the "black" class (CONAB, 2019). White beans, despite their consumption in smaller quantities when compared with other classes, have aroused the interest of researchers, mainly with regard to the use of their compounds in the food industry, as they present higher digestibility than the other two classes (Cavalcanti et al., 2018).

In order to obtain the best-quality grains in the harvest, that is, to reach the maximum dry matter content and market value, drying should be carried out at the moment of physiological maturity. However, at this stage, the grains have a high water content, which hinders harvesting and processing operations in addition to causing mechanical damage and accelerated deterioration during storage (Andrade et al., 2010).

Conservation by drying is based on the fact that microorganisms, enzymes, and the entire metabolic machinery need water to carry out biochemical processes. The phenomenon of reducing the water content of grains involves, simultaneously, the transfer of heat and mass, which can substantially alter the quality and physical properties of the product, depending on the method and conditions of drying (Morais et al., 2013; Costa et al., 2016; Corrêa et al., 2017). A cereal or grain is hygroscopic in nature, so it can gain or lose water, depending on the relative humidity of the space where it is located or the vapor pressure generated by the water content itself, phenomena known as water adsorption and desorption, respectively (Corrêa et al., 2014). The equilibrium water content is reached when the partial pressure of water vapor in the

${ }^{1}$ Federal University of Vicosa, UFV - Vicosa Campus/ Minas Gerais - MG, Brazil.

${ }^{2}$ Goiás Technical Assistance Agency, Rural Eextension and Agricultural Research - EMATER/ Goiânia - GO, Brazil.

${ }^{3}$ Federal University of Espírito Santo, UFES - Alegre Campus/ Espírito Santo - ES, Brazil.

${ }^{4}$ Federal Institute of the North of Minas Gerais. IFNMG - Arinos Campus/ Minas Gerais - MG, Brazil.

Editor: Gizele Ingrid Gadotti

Received in: 10-17-2018

Accepted in: 2-12-2021 
product equals that of the surrounding air. The relationship between the water content of a given product and the relative equilibrium humidity, or water activity, for a specific temperature, can be expressed by mathematical equations, called isotherms or hygroscopic equilibrium curves (Corrêa et al., 2014).

In drying processes and in the storage of agricultural products, knowledge of thermodynamic properties is used in the analysis of sorption behavior in biological systems. Its study is indispensable in the search for solutions to problems related to stability issues and in the optimization of the conditions of industrial processes (Corrêa et al., 2017; Oliveira et al., 2017). Cavalcanti et al. (2018), studying thermodynamic properties of white bean seeds, concluded that the isosteric heat of desorption is increased 20 to 21 times when the water content is reduced from 0.30 to 0.05 on a dry basis (d.b.).

Given the above, considering the importance of knowledge of the thermodynamic properties of agricultural products, we aimed to determine the hygroscopic equilibrium isotherms and to evaluate the following thermodynamic properties of white bean grains (Phaseolus vulgaris L.), BRS Ártico cultivar: isosteric heat of sorption, entropy and differential enthalpy of desorption and enthalpy-entropy compensation theory, calculated from sorption isotherms, for different equilibrium conditions: temperatures of $18,27,38$, and $50{ }^{\circ} \mathrm{C}$ and humidity between $19 \%$ and $78 \%$.

\section{MATERIAL AND METHODS}

This study was carried out at the Laboratory of Physical Properties and Quality Evaluation of Agricultural Products, at National Storage Training Center (Centro Nacional de Treinamento em Armazenagem - Centreinar), located on the Federal University of Viçosa campus (UFV), Viçosa - Minas Gerais (2045'00" S, 42 $56^{\prime} 15^{\prime \prime} \mathrm{W}$; $643 \mathrm{~m}$ altitude), Brazil.
White bean grains (Phaseolus vulgaris L.), cultivar BRS Ártico, with an initial water content of 0.142 on a dry basis (d.b.), acquired in the local market, were used. The grains were submitted to drying in an oven with forced air ventilation, at a temperature of $40^{\circ} \mathrm{C}$ and a relative humidity of $23.4 \%$, until they reached an equilibrium water content of $0.075,0.086,0.116,0.192$, and 0.215 (d.b.). The initial and equilibrium water contents, in d.b., were determined by the standard greenhouse method, at $105 \pm 2{ }^{\circ} \mathrm{C}$, for $24 \mathrm{~h}$, in three repetitions (Brasil, 2009).

To obtain hygroscopic balance, 5 samples of $15 \mathrm{~g}$ were inserted into desiccators, which contained saturated solutions of lithium chloride, potassium acetate, magnesium chloride, magnesium carbonate, and sodium bromide. That is, in each desiccator, about $600 \mathrm{ml}$ of saturated solution formed with one of the aforementioned salts was added.

The samples remained on "crucibles". The desiccators were kept in climatic chambers (model $347 \mathrm{CD}$, Fanem brand) at temperatures of $18,27,38$, and $50{ }^{\circ} \mathrm{C}$. Relative humidity levels were established that varied from $19 \%$ to $78 \%$. Control took place by means of a temperature and relative humidity transmitter (Model RHT-AIR, Novus brand). During this stage, the samples were weighed periodically on an analytical balance (model AY220, Marte brand), with an accuracy of $0.001 \mathrm{~g}$, to monitor the variation in mass. When this variation did not exceed $2 \%$ between three consecutive weight measurements, the grains were considered in hygroscopic equilibrium.

Water activity was measured using the Aqualab BrasEq 4TE apparatus, model 4TE series, series S40001101.

The observed hygroscopic balance data obtained for each temperature and relative humidity condition were fitted to mathematical models commonly used to describe the sorption phenomena in agricultural products. The models used are shown in Table 1 .

TABLE 1. Mathematical models used to represent hygroscopic equilibrium curves.

\begin{tabular}{|c|c|c|}
\hline Models & Equation & \\
\hline Copace & $\mathrm{Xe}=\exp \left[(\mathrm{a}-\mathrm{b} \cdot \mathrm{T})+\mathrm{c} \cdot \mathrm{a}_{\mathrm{w}}\right]$ & (1) \\
\hline Sigma-Copace & $\mathrm{Xe}=\exp \left\{\mathrm{a}-\mathrm{b} \cdot \mathrm{T}+\left[\mathrm{c} \cdot \exp \left(\mathrm{a}_{\mathrm{w}}\right)\right]\right\}$ & (2) \\
\hline Sigma-Copace II & $\mathrm{Xe}=1 /\left(\mathrm{a} \cdot \mathrm{T} \cdot \mathrm{b}+\mathrm{a}_{\mathrm{w}} \cdot \mathrm{c}\right)$ & (3) \\
\hline Copace 3 & $X e=\exp \left(a+b / T+c \cdot a_{w}{ }^{3}\right)$ & (4) \\
\hline modified Henderson & $\mathrm{Xe}=\left\{\log \left(1-\mathrm{a}_{\mathrm{w}}\right) /[-\mathrm{a}(\mathrm{T}+\mathrm{b})]\right\}^{1 / \mathrm{c}}$ & (5) \\
\hline Chung P-foste & $\mathrm{Xe}=\mathrm{a}-\mathrm{b} \cdot \ln \left[(\mathrm{c}-\mathrm{T}) \cdot \ln \left(\mathrm{a}_{\mathrm{w}}\right)\right]$ & (6) \\
\hline $\mathrm{COP}$ & $\mathrm{Xe}=\exp \left(\mathrm{a}-\mathrm{b} \cdot \mathrm{T}+\mathrm{c} \cdot \mathrm{a}_{\mathrm{w}}\right)$ & (7) \\
\hline Frend & $\mathrm{Xe}=\mathrm{a} \cdot\left(\mathrm{a}_{\mathrm{w}}{ }^{1 / \mathrm{b}}\right)$ & (8) \\
\hline modified Oswin & $\mathrm{Xe}=(\mathrm{a}+\mathrm{b} \cdot \mathrm{T}) \cdot\left[\mathrm{a}_{\mathrm{w}} /\left(1-\mathrm{a}_{\mathrm{w}}\right)\right]^{1 / \mathrm{c}}$ & (9) \\
\hline Scop & $\mathrm{Xe}=\exp \left[\mathrm{a}-\mathrm{b} \cdot \mathrm{T}+\mathrm{c} \cdot \exp \left(\mathrm{a}_{\mathrm{w}}\right)\right]$ & (10) \\
\hline Smith & $\mathrm{Xe}=\mathrm{a}-\mathrm{b} \cdot \mathrm{T}-\mathrm{c} \cdot \log \left(1-\mathrm{a}_{\mathrm{w}}\right)$ & (11) \\
\hline Halsey & $\mathrm{Xe}=\left\{\exp (\mathrm{a}-\mathrm{b} \cdot \mathrm{T}) /\left[-\log \left(\mathrm{a}_{\mathrm{w}}\right)\right]\right\}^{1 / \mathrm{c}}$ & (12) \\
\hline modified Halsey & $\mathrm{Xe}=\left\{\exp (\mathrm{a}-\mathrm{bT}) /\left[-\ln \left(\mathrm{a}_{\mathrm{w}}\right)\right]\right\}^{1 / \mathrm{c}}$ & (13) \\
\hline Harkins & $\mathrm{Xe}=[\exp (\mathrm{a}-\mathrm{b} \cdot \mathrm{T})] /\left[\mathrm{c}-\log \left(\mathrm{a}_{\mathrm{w}}\right)\right]$ & (14) \\
\hline Iglesias & $\mathrm{Xe}=(\mathrm{a}+\mathrm{b} \cdot \mathrm{T}) \cdot\left[\mathrm{a}_{\mathrm{w}} /\left(1-\mathrm{a}_{\mathrm{w}}\right)\right]+\mathrm{c}$ & (15) \\
\hline
\end{tabular}


in which:

$\mathrm{Xe}$ - equilibrium water content $\left(\mathrm{kg}_{\mathrm{a}} \mathrm{kg}_{\mathrm{ms}}{ }^{-1}\right)$;

$\mathrm{a}_{\mathrm{w}}$ - water activity (decimal);

$\mathrm{T}$ - temperature $\left({ }^{\circ} \mathrm{C}\right)$,

$\mathrm{a}, \mathrm{b}$ and $\mathrm{c}$ - coefficients that depend on the product.

\section{Statistical analysis}

The mathematical models were adjusted by nonlinear regression using the Gauss-Newton method with the Statistica $8.0^{\circledR}$ software. In selecting the best model to predict the equilibrium water content of white bean grains, the following were considered: magnitude of the coefficient of determination $\left(\mathrm{R}^{2}\right)$, relative average error $(\mathrm{P})$, estimated standard deviation (SE) and residue distribution, also called Trend, (distribution of residues in relation to the values estimated by the model).

The values of $\mathrm{P}$ and $\mathrm{SE}$ for each mathematical model were calculated with eqs (16) and (17), respectively.

$$
\mathrm{P}=\frac{100}{\mathrm{n}} \sum_{\mathrm{i}=1}^{\mathrm{n}} \frac{\left|\mathrm{Y}_{\mathrm{i}}-\widehat{\mathrm{Y}}_{\mathrm{i}}\right|}{\mathrm{Y}_{\mathrm{i}}}(16) \quad \mathrm{SE}=\sqrt{\frac{\sum_{\mathrm{i}=1}^{\mathrm{n}}\left(\mathrm{Y}_{\mathrm{i}}-\widehat{\mathrm{Y}}_{\mathrm{i}}\right)^{2}}{\mathrm{GLR}}}
$$

in which:

$$
\begin{aligned}
& \mathrm{Y}_{\mathrm{i}} \text { - observed experimental value; } \\
& \hat{\mathrm{Y}}_{\mathrm{i}} \text { - value estimated by the model; } \\
& \mathrm{n} \text { - number of observed data values, }
\end{aligned}
$$

GLR - degrees of freedom of the residue (number of data values observed minus the number of model parameters).

After the model was chosen, isotherms were built at each temperature to represent the phenomenon of desorption of white bean grains under the studied conditions. From the values determined by the mathematical model chosen, the thermodynamic properties were determined.

\section{Thermodynamic properties}

For the calculation of the liquid isosteric heat of sorption (or differential enthalpy), for each equilibrium water content, the Clausius-Clayperon equation (Equation 18) was used (Iglesias \& Chirife, 1976).

$$
\frac{\partial \ln \left(\mathrm{a}_{\mathrm{w}}\right)}{\partial \mathrm{T}}=\frac{\Delta \mathrm{h}_{\mathrm{st}}}{\mathrm{RT}_{\mathrm{a}}^{2}}
$$

in which:

$$
\begin{aligned}
& \mathrm{a}_{\mathrm{w}} \text { - water activity (decimal); } \\
& \mathrm{T}_{\mathrm{a}} \text { - absolute temperature }(\mathrm{K}) ; \\
& \Delta \mathrm{h}_{\mathrm{st}} \text { - differential enthalpy }\left(\mathrm{kJ} \mathrm{kg}^{-1}\right), \\
& \mathrm{R} \text { - universal gas constant }\left(8.314 \mathrm{~kJ} \mathrm{kmol}^{-1} \mathrm{~K}^{-1}\right) \text {, } \\
& \text { being, for steam, } 0.4619 \mathrm{~kJ} \mathrm{~kg}^{-1} \mathrm{~K}^{-1} \text {. }
\end{aligned}
$$

Integrating [eq. (18)] and assuming that the liquid isosteric heat of sorption is independent of temperature, this property was determined for each equilibrium water content according to [eq. (19)] (Wang \& Brennan, 1991).

$$
\ln \left(\mathrm{a}_{\mathrm{w}}\right)=-\left(\frac{\Delta \mathrm{h}_{\mathrm{st}}}{\mathrm{R}}\right) \cdot \frac{1}{\mathrm{~T}}+\mathrm{C}
$$

in which:

$$
\text { C - model coefficient. }
$$

The integral isosteric heat of sorption was obtained by adding the liquid isosteric heat of sorption and the latent heat of vaporization of free water, defined by [eq. (20)].

$$
\mathrm{Q}_{\mathrm{st}}=\Delta \mathrm{h}_{\mathrm{st}}+\mathrm{L}=\mathrm{a} \cdot \exp \left(-\mathrm{b} \cdot \mathrm{Xe}^{*}\right)+\mathrm{L}
$$

in which:

$\mathrm{Q}_{\mathrm{st}}$ - integral isosteric heat of sorption $\left(\mathrm{kJ} \mathrm{kg}^{-1}\right)$;

$\mathrm{L}$ - latent heat of free water vaporization $\left(\mathrm{kJ} \mathrm{kg}^{-1}\right)$;

$\mathrm{Xe}^{*}$ - equilibrium water content (\% b.s.),

$\mathrm{a}$ and $\mathrm{b}$ - model coefficients.

The latent heat of vaporization of free water, at equilibrium temperature $\left({ }^{\circ} \mathrm{C}\right)$, was calculated using the average temperature $(\mathrm{T})$ in the range under study, 18, 27, 38 , and $50^{\circ} \mathrm{C}$, with the aid of [eq. (21)].

$$
\mathrm{L}=2502.2-2.39 \mathrm{~T}
$$

Differential sorption entropy was calculated from the Gibbs-Helmholtz equation (Equation 22) (Rizvi, 2014).

$$
\Delta \mathrm{S}=\frac{\Delta \mathrm{h}_{\mathrm{st}}-\Delta \mathrm{G}}{\mathrm{T}_{\mathrm{a}}}
$$

in which:

$$
\begin{aligned}
& \Delta \mathrm{S} \text { - differential sorption entropy }\left(\mathrm{kJ} \mathrm{kg}^{-1} \mathrm{~K}^{-1}\right), \\
& \Delta \mathrm{G}-\text { Gibbs free energy }\left(\mathrm{kJ} \mathrm{kg}^{-1}\right) .
\end{aligned}
$$

The Gibbs free energy calculation was applied to analyze the spontaneity of the water gain and loss processes between the product and the environment, as indicated by Oliveira et al. (2014). A negative value of Gibbs free energy indicates that the process is spontaneous, and a positive value means that it is not spontaneous. A zero value means that equilibrium has been reached in relation to the spontaneity of the process (Corrêa et al., 2010). According to Oliveira et al. (2013), Gibbs free energy $(\Delta \mathrm{G})$ can be estimated using [eq. (23)].

$$
\Delta \mathrm{G}=\mathrm{R} \cdot \mathrm{T} \cdot \ln \left(\mathrm{a}_{\mathrm{w}}\right)
$$

The effects of changes in water sorption on free energy are usually accompanied by changes in enthalpy and entropy values. Thus, substituting [eq. (23)] into [eq. (22)] give [eq. (24)].

$$
\ln \left(\mathrm{a}_{\mathrm{w}}\right)=\frac{\Delta \mathrm{h}_{\mathrm{st}}}{\mathrm{R} \cdot \mathrm{T}}-\frac{\Delta \mathrm{S}}{\mathrm{R}}
$$

The calculated values of differential sorption enthalpy $\left(\Delta \mathrm{h}_{\mathrm{st}}\right)$ and entropy $(\Delta \mathrm{S})$ were correlated by [eq. (25)] (Beristain et al., 1996).

$$
\Delta \mathrm{h}_{\mathrm{st}}=T_{B}(\Delta \mathrm{S})+\Delta \mathrm{GB}
$$

in which: 
$\mathrm{T}_{\mathrm{B}}$ - isokinetic temperature (K),

$\Delta \mathrm{GB}$ - Gibbs free energy at isokinetic temperature $\left(\mathrm{kJ} \mathrm{kg}^{-1}\right)$.

The isokinetic temperature represents the temperature at which all reactions in a series occur at the same rate. Since enthalpy and entropy are highly correlated, it is assumed that the compensation theory may be valid for sorption (Beristain et al., 1996). To confirm the existence of compensation, the isokinetic temperature was compared with the harmonic mean of the temperatures used to determine the sorption isotherms, according to [eq. (26)] (Krug et al., 1976a, 1976b).

$$
\mathrm{T}_{\mathrm{hm}}=\frac{\mathrm{n}}{\sum\left(\frac{1}{\mathrm{~T}}\right)}
$$

in which:

$$
\begin{aligned}
& \mathrm{T}_{\mathrm{hm}} \text { - harmonic mean temperature }(\mathrm{K}), \\
& \mathrm{n} \text { - number of temperatures used. }
\end{aligned}
$$

According to Krug et al. (1976a; 1976b), linear chemical compensation, or compensation theory, only exists if the isokinetic temperature $\left(T_{B}\right)$ is different from the harmonic mean temperature $\left(\mathrm{T}_{\mathrm{hm}}\right)$. An approximate confidence interval $(1-\alpha ; 100 \%)$ for isokinetic temperature was calculated using [eq. (27)].

$$
\mathrm{T}_{\mathrm{B}}=\widehat{\mathrm{T}}_{\mathrm{B}} \pm \mathrm{t}_{\mathrm{m}-2, \alpha / 2 \sqrt{\operatorname{var}(\mathrm{TB})}}
$$

in which:

$$
\begin{gathered}
\widehat{\mathrm{T}_{\mathrm{B}}}=\frac{\sum\left(\Delta \mathrm{h}_{\mathrm{st}}-\overline{\Delta \mathrm{h}_{\mathrm{st}}}\right)(\Delta \mathrm{S}-\overline{\Delta \mathrm{S}})}{\sum(\Delta \mathrm{S}-\overline{\Delta \mathrm{S}})^{2}} \\
\operatorname{Var}\left(\mathrm{T}_{\mathrm{B}}\right)=\frac{\sum\left(\Delta \mathrm{h}_{\mathrm{st}}-\overline{\Delta \mathrm{G}_{\mathrm{B}}}-\widehat{\mathrm{T}_{\mathrm{B}}} \cdot \Delta \mathrm{S}\right)^{2}}{(\mathrm{~m}-2) \sum(\Delta \mathrm{S}-\overline{\Delta \mathrm{S}})^{2}}
\end{gathered}
$$

in which:

$\mathrm{m}$ - number of enthalpy and entropy data pairs;

$\Delta \mathrm{h}_{\mathrm{st}}$ - mean enthalpy $\left(\mathrm{kJ} \mathrm{kg}^{-1}\right)$,

$\Delta \mathrm{S}$ - mean entropy $\left(\mathrm{kJ} \mathrm{kg}^{-1}\right)$.

If the harmonic mean of the temperature $\left(\mathrm{T}_{\mathrm{hm}}\right)$ is within the range calculated for the isokinetic temperature $\left(\mathrm{T}_{\mathrm{B}}\right)$, the relationship between enthalpy values and differential sorption entropy reflects only experimental errors and not the existence of chemical and physical factors that react to the compensation theory (Beristain et al., 1996). For $\mathrm{T}_{\mathrm{B}}$, a $99 \%$ confidence interval was adopted for the entire range of observed data.

\section{RESULTS AND DISCUSSION}

Table 2 shows the parameter estimates for the models adjusted to the water content data for hygroscopic balance in white beans, at different levels, for temperature conditions varying from 18 to $50{ }^{\circ} \mathrm{C}$ and relative air humidity varying from $19 \%$ to $78 \%$. Table 2 also presents the respective values of determination coefficient $\left(\mathrm{R}^{2}\right)$, relative mean error $(\mathrm{P})$, standard deviation of the estimate (SE), and the trend for each model.

TABLE 2. Estimates of the parameters of the hygroscopic equilibrium models of white beans for the temperature range of 18 to $50{ }^{\circ} \mathrm{C}$.

\begin{tabular}{lccccccc}
\hline \multirow{2}{*}{ Models } & \multicolumn{3}{c}{ Model variables } & \multicolumn{4}{c}{ Statistical variables } \\
\cline { 2 - 7 } Copace & $\mathrm{a}$ & $\mathrm{b}$ & $\mathrm{c}$ & $\mathrm{R}^{2}$ & $\mathrm{P}$ & $\mathrm{SE}$ & Residual distribution \\
Sigma-Copace & 1.653 & 0.006 & 2.072 & 0996 & 3908 & 0.580 & Random \\
Copace 3 & 0.678 & 0.006 & 1.196 & 0.997 & 3.387 & 0.480 & Random \\
Sigma-Copace II & 1.912 & 4.901 & 2.189 & 0.986 & 6.836 & 1.023 & Blased \\
Modified Henderson & -5769.095 & -4.068 & 1.420 & 0.000 & 571.704 & 13.473 & Blased \\
Chung P-foste & 0.000 & 82.284 & 1.468 & 0.991 & 12.298 & 6.058 & Random \\
COP & 47.129 & 8.261 & 59.863 & 0.990 & 7.308 & 0.882 & Blased \\
Frend & 1.653 & 0.006 & 2.072 & 0.996 & 3.908 & 0.580 & Blased \\
Modified Oswin & 26.943 & 0.975 & & 0.964 & 12.282 & 1.646 & Random \\
Oswin & 14.459 & -0.072 & 2.132 & 0.996 & 4.061 & 0.576 & Random \\
Smith & -965.678 & 5.006 & 5629.196 & 0.116 & 98.259 & 23.412 & Blased \\
Sabbab & 6.929 & 0.091 & 11.795 & 0.997 & 3.683 & 0.477 & Random \\
Modified Halsey & 49.745 & 1.016 & 0.181 & 0.980 & 23.600 & 5.600 & Blased \\
Harkins & 3.836 & 0.009 & 1.587 & 0.997 & 3.368 & 0.501 & Random \\
Iglesias & 2.687 & 0.006 & 0.308 & 0.996 & 4.085 & 0.588 & Random \\
\hline
\end{tabular}

a, b, c: coefficients that depend on the product; $\mathrm{R}^{2}$ : determination coefficient; P: relative mean error and SE: standard deviation of the estimate. 
Several authors argue that a model fits the data well if the value of the relative average error $(\mathrm{P})$ is less than $10 \%$ (Corrêa et al., 2014; Costa et al., 2015). According to Kashaninejad et al. (2007), the values of the relative average error $(\mathrm{P})$ indicate deviation from the observed values, in relation to the curve estimated by the model. In the report by Radünz et al. (2014), the model's fidelity in describing a particular physical process is inversely proportional to the value of the relative average error $(\mathrm{P})$. Therefore, the lower the value of the relative average error, the better the quality of fit of the model in relation to the observed data. Likewise, the smaller the value of the standard deviation of the estimate (SE), better the fit of the model.

Table 2 shows that the models that best suited the experimental data were Copace, Sigma-Copace, modified

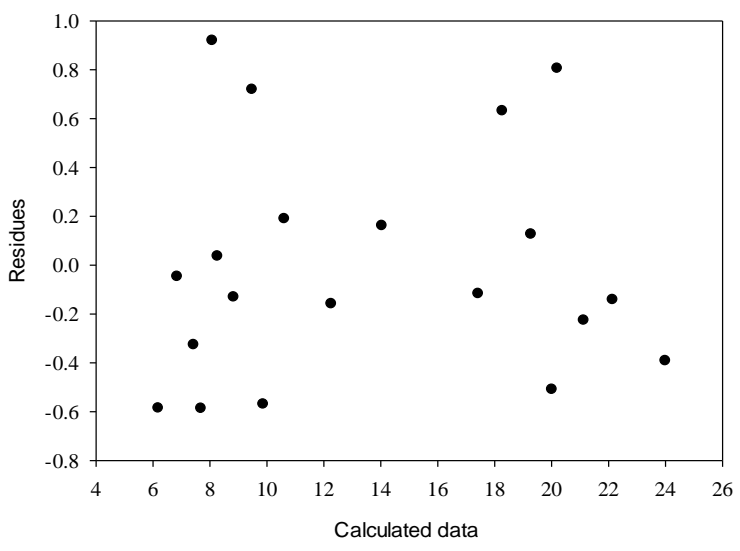

a.
Oswin, Smith, modified Halsey, and Harkins: these models presented satisfactory values of the coefficient of determination $\left(\mathrm{R}^{2}\right)$, greater than $99 \%$, and reduced values of the standard deviation of the estimate (SE) and the relative average error $(\mathrm{P})$. In addition, these models did not show a trend regarding the dispersion of waste. Among these, the one with the highest $R^{2}(0.997)$ and a better fit with respect to $P$ values (3.387) and SE (0.480) was Sigma-Copace; therefore, this will be the model used for the construction of white bean desorption isotherms and other thermodynamic calculations.

In Figure 1a, the trend graph of the distribution of residues for the Sigma-Copace model is observed as a function of the estimated values of the hygroscopic balance of white beans and in Figure 1b, the correlation of the experimental and estimated values by the same model.

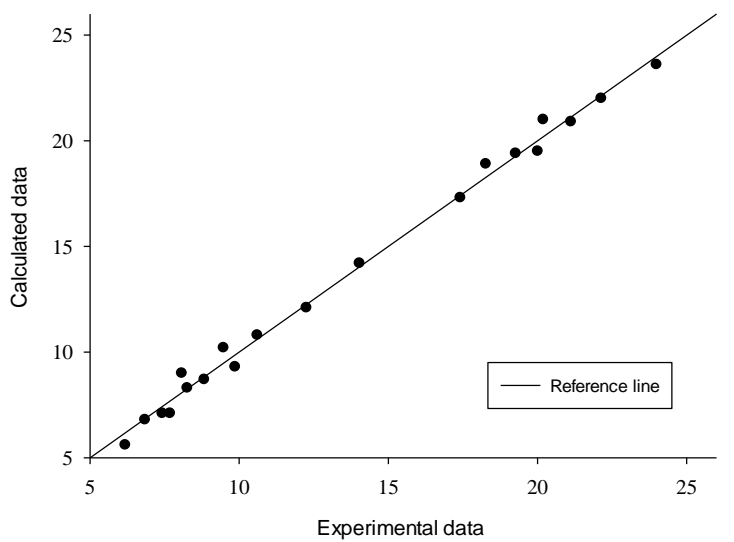

b.

FIGURE 1. Residual distribution for the Sigma-Copace model (a) and correspondence between calculated and experimental values (b).

Figure 1a. shows that the residues are randomly distributed in the Sigma-Copace model, and in Figure 1b., it appears that the values calculated by this model are similar to those found experimentally, due to the proximity to the reference line $\left(45^{\circ}\right)$.
Figure 2 shows the graph with the observed values and the sorption isotherms estimated by the Sigma-Copace model for temperatures of $18,27,38$, and $50^{\circ} \mathrm{C}$.

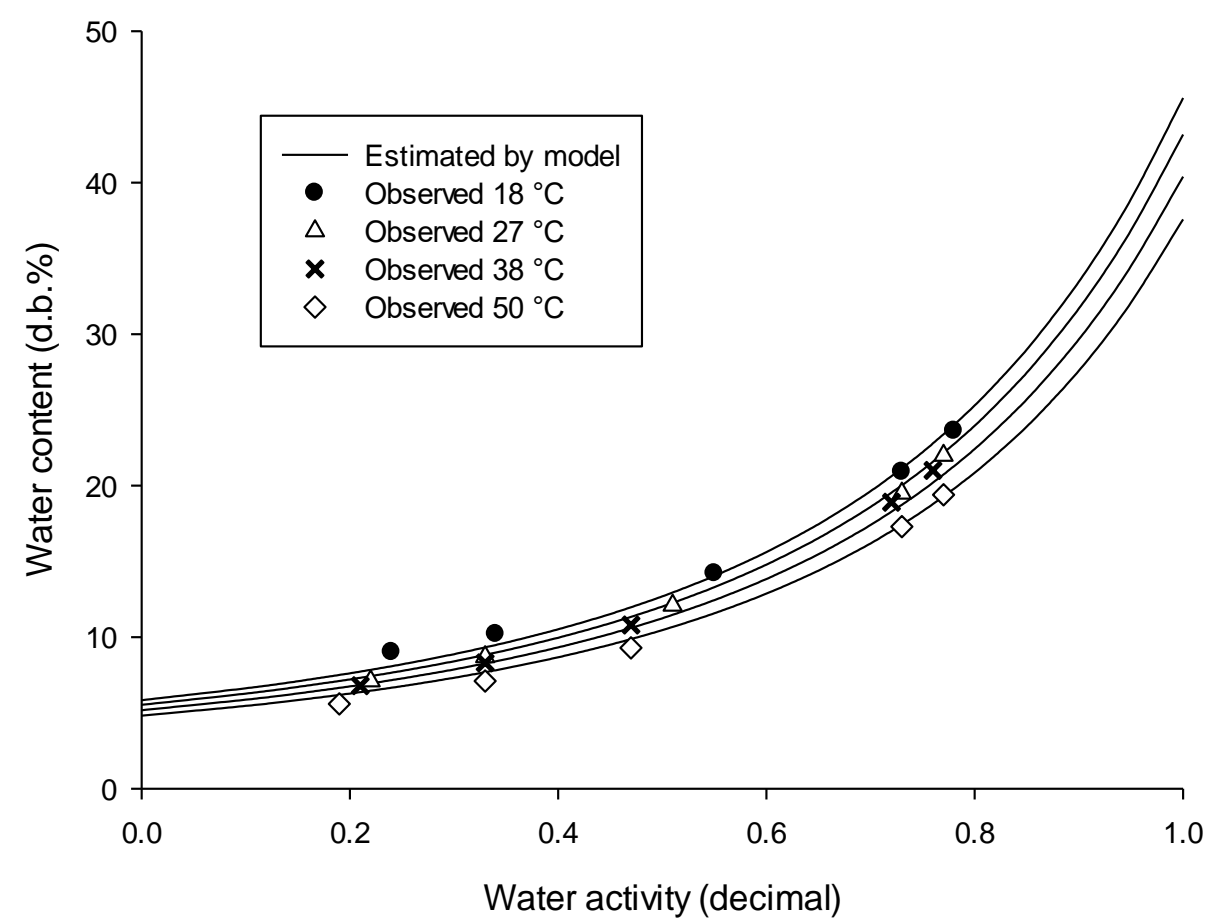

FIGURE 2. Observed values and sorption isotherms estimated by the Sigma-Copace model for temperatures of $18,27,38$, and $50^{\circ} \mathrm{C}$. 
As shown in Figure 2, with the increase in water content, there was an increase in water activity, the same effect being observed with the increase in temperature. The generated Sigma-Copace model is presented in Equation 30. According to Palipane \& Driscoll (1993), as the temperature increases, the water molecules reach energy levels at which they become thermodynamically less stable, favoring breakage of connections between the water and the sorption sites, thus reducing the water content in the product.

$$
\mathrm{Xe}=\exp \left[0.678-0.006 \mathrm{~T}+1.196 \exp \left(\mathrm{a}_{\mathrm{w}}\right)\right]
$$

Other authors have also found that the SigmaCopace mathematical model could be used to describe the hygroscopic balance of several products, such as Costa et al. (2015) for crambe fruits, Corrêa et al. (2014) for cherry coffee fruits, and Corrêa et al. (2016) for roasted coffee in different granulometries. Cavalcanti \& Rosa (2016) found that Oswin's mathematical model was the one that best suited the experimental data for constructing white bean seed desorption isotherms.

The water activities estimated by the Sigma-Copace model (Equation 30) for temperatures of 18, 27, 38, and 50 ${ }^{\circ} \mathrm{C}$ and for equilibrium water contents of 0.068 to 0.236 (d.b.) are shown in Table 3.

TABLE 3. Water activity values (decimal) estimated by the Sigma-Copace model, as a function of temperature and equilibrium water content $(\mathrm{Xe})$.

\begin{tabular}{ccccc}
\hline \multirow{2}{*}{$\mathrm{Xe}$} & \multicolumn{3}{c}{ Temperature $\left({ }^{\circ} \mathrm{C}\right)$} \\
\cline { 2 - 5 } & 18 & 27 & 38 & 50 \\
\hline 6.8 & 0.1196 & 0.1591 & 0.2053 & 0.2535 \\
7.1 & 0.1511 & 0.1894 & 0.2343 & 0.2811 \\
8.3 & 0.2575 & 0.2920 & 0.3326 & 0.3751 \\
8.7 & 0.2875 & 0.3210 & 0.3605 & 0.4018 \\
9.0 & 0.3085 & 0.3414 & 0.3800 & 0.4206 \\
9.3 & 0.3285 & 0.3607 & 0.3986 & 0.4385 \\
10.2 & 0.3826 & 0.4131 & 0.4492 & 0.4871 \\
10.8 & 0.4147 & 0.4443 & 0.4792 & 0.5160 \\
12.1 & 0.4756 & 0.5034 & 0.5364 & 0.5712 \\
14.2 & 0.5555 & 0.5812 & 0.6118 & 0.6441 \\
17.3 & 0.6460 & 0.6696 & 0.6976 & 0.7273 \\
18.9 & 0.6841 & 0.7067 & 0.7338 & 0.7624 \\
19.4 & 0.6950 & 0.7175 & 0.7442 & 0.7725 \\
19.5 & 0.6972 & 0.7196 & 0.7462 & 0.7745 \\
20.9 & 0.7257 & 0.7474 & 0.7733 & 0.8009 \\
21.0 & 0.7276 & 0.7493 & 0.7752 & 0.8027 \\
22.0 & 0.7462 & 0.7675 & 0.7930 & 0.8200 \\
23.6 & 0.7737 & 0.7944 & 0.8192 & 0.8455 \\
\hline
\end{tabular}

The values of water activity (Table 3 ) were used to determine the values of differential enthalpy and differential entropy of desorption.

Figure 3 shows the curves of the Neperian logarithm of water activity (decimal), calculated from the SigmaCopace equation, for specific values of equilibrium water content (\% d.b.), as a function of values of the inverse of absolute temperature $(\mathrm{K})$, for the white bean grains used. 


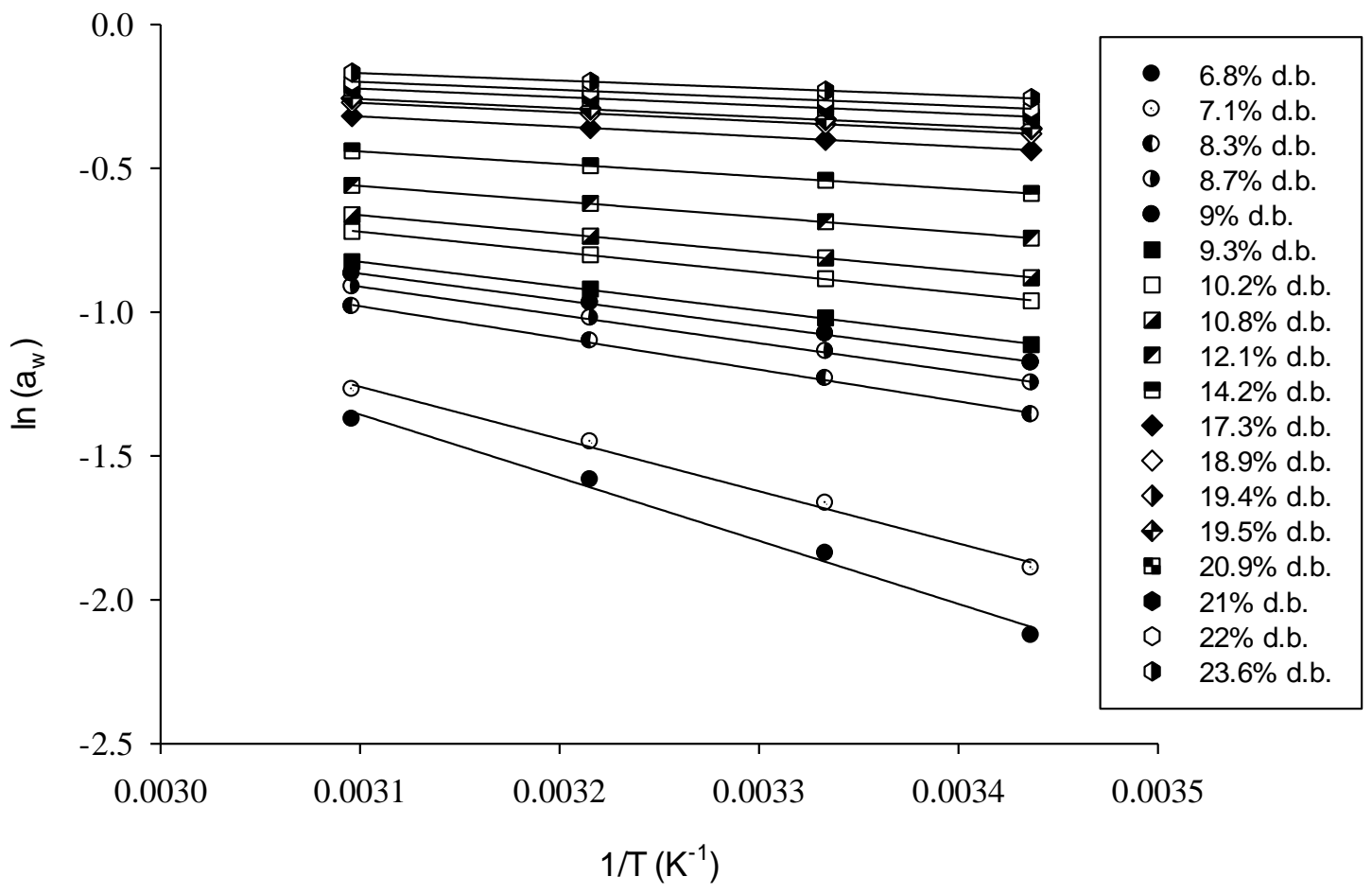

FIGURE 3. Curves of the Neperian logarithm of water activity (decimal), for specific values of equilibrium water content (\% d.b.), according to values of $1 / \mathrm{T}\left(\mathrm{K}^{-1}\right)$, for white bean grains.

Differential enthalpy values $\left(\Delta \mathrm{h}_{\mathrm{st}}\right)$ for white bean grains, depending on the equilibrium water content (\% d.b.), were determined according to the equation proposed by Wang \& Brennan (1991) and represented, for each condition, by the slopes of the lines shown in Figure 3. The values of the integral isosteric heat of the white bean grains varied from $2.543 \mathrm{~kJ} \mathrm{~kg}^{-1}$ to $3.437 \mathrm{~kJ} \mathrm{~kg}^{-1}$, for the water content range of 0.236 ( $23.6 \%$ d.b.) to $0.068 \%$ (6.8\% d.b.) (Figure $4 \mathrm{a}$ ). It was found that, with the reduction in water content, there was an increase in the energy required to remove water from the product, represented by the values of the integral isosteric heat of desorption $\left(\mathrm{Q}_{\mathrm{st}}\right)$, as noted by Oliveira et al. (2013), Teixeira et al. (2018) and Cavalcanti et al. (2018) studying, corn, pumpkin seed and white bean grains, respectively.

According to Brooker et al. (1992), a higher amount of energy is required to remove water from products with a low water content, when compared with wet products. This is because, in the initial phase of sorption (lower water content), there are monomolecular layers that require high amounts of energy to remove the water molecules in them from the product (Al-Muhtaseb et al., 2004).
Differential entropy was found to be strongly related to the water content of the grains, presenting values of $0.2954 \mathrm{~kJ} \mathrm{~kg}^{-1} \mathrm{~K}^{-1}$ to $2.5173 \mathrm{~kJ} \mathrm{~kg}^{-1} \mathrm{~K}^{-1}$ (Figure $4 \mathrm{~b}$ ). With the increase in water content, a decrease in differential entropy was observed. This behavior is related to the mobility of water molecules present during the desorption process. With the high water activity, there are fewer places available for the bonds between the molecules, implying less demand for mobility of the water molecules (Goneli et al., 2010). Similar behavior was observed by Teixeira et al. (2018) and Silva et al. (2015), studying pumpkin and pepper seeds, respectively.

The representation of the relationship between enthalpy and entropy, in the desorption process for bean grains, was adjusted according to a linear regression, presenting a high coefficient of determination (99.92\%) (Figure $4 c$ ). With the linearity between the differential enthalpy ratio and the differential sorption entropy, the isokinetic theory, or enthalpy-entropy compensation theory, can be considered valid for the water desorption phenomenon. Corrêa et al. (2015a) and Hassini et al. (2015) observed the same behavior for coffee and "prickly" pear seeds, respectively. 
a.

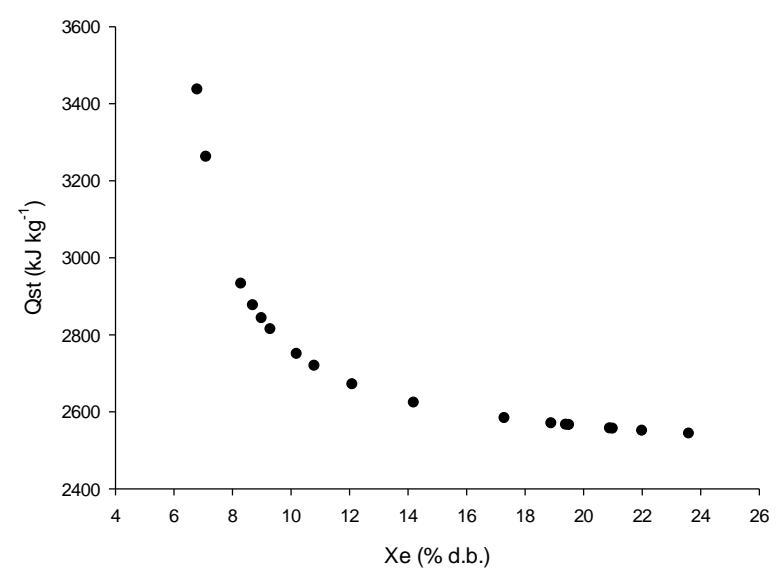

b.

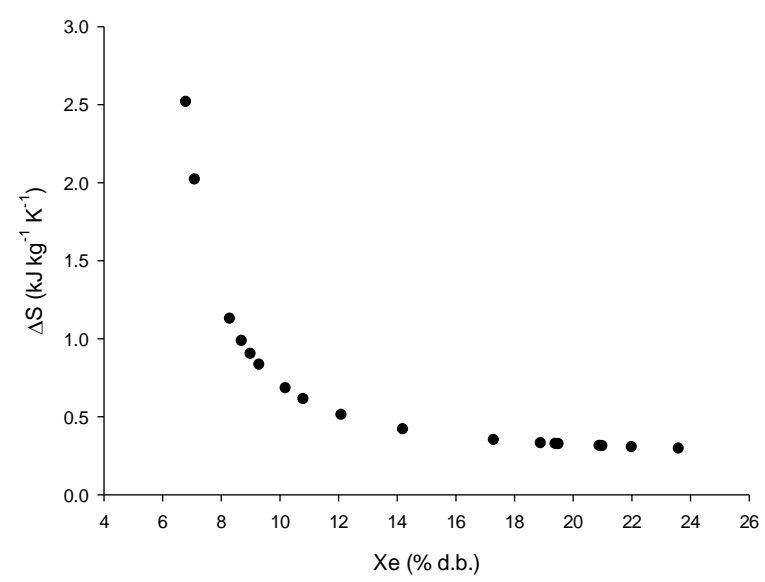

c.

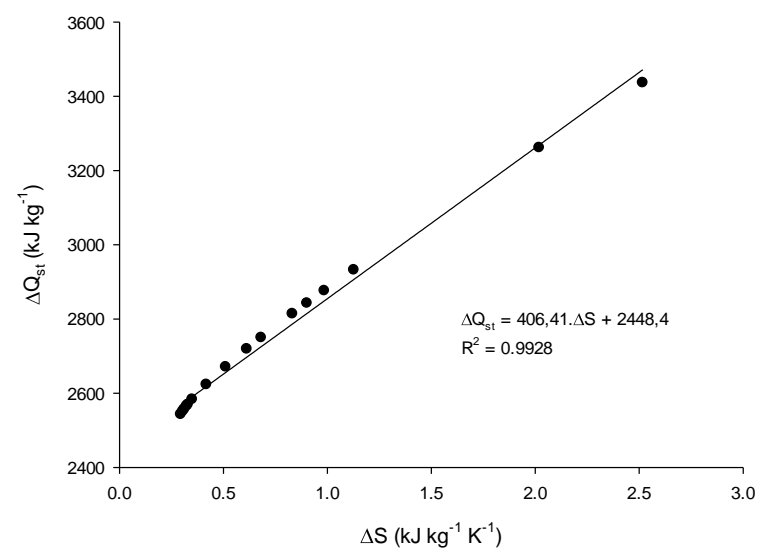

FIGURE 4. Experimental and estimated values of the integral isosteric heat of desorption, Qst (a), differential entropy of desorption, $\Delta \mathrm{S}(\mathrm{b})$, and enthalpy-entropy linear relationship, $\Delta \mathrm{Q}_{\mathrm{st}}$ (c), for the desorption process, depending on the equilibrium water content of white bean grains.

To test the validity of the enthalpy-entropy compensation theory, the isokinetic temperature was compared with the harmonic mean $\left(\mathrm{T}_{\mathrm{hm}}\right)$ in the studied temperature range, used to determine the desorption process. In enthalpy-entropy linear compensation, it was found that, if $\mathrm{T}_{\mathrm{B}}>\mathrm{T}_{\mathrm{hm}}$, the process is controlled by enthalpy; otherwise (if $\mathrm{T}_{\mathrm{B}}<\mathrm{T}_{\mathrm{hm}}$ ), the process is controlled by entropy (Ryde, 2014). The isokinetic temperature for the desorption of bean grains was $406.41 \pm 10.48 \mathrm{~K}$ and from $395.93 \mathrm{~K}$ to $416.89 \mathrm{~K}$. The calculated harmonic mean was $305.78 \mathrm{~K}$, which was significantly different from the isokinetic temperature values described, confirming the enthalpy-entropy compensation phenomenon for the desorption process.

The harmonic mean was outside the isokinetic temperature range and was also different from the isokinetic temperature. This isokinetic temperature was higher than the temperature of the harmonic mean, showing that the process is controlled by enthalpy. These results are in line with the observations of several researchers, who successfully applied the isokinetic theory to the sorption of various agricultural products (Oliveira et al., 2014, 2017; Kurozawa et al., 2015; Silva et al., 2015).

Gibbs free energy increased with decreasing water content and was positive for all temperatures studied, with a tendency to stabilize at higher levels of equilibrium water content (Figure 5a). This trend was also observed by Corrêa et al. (2015b) and Silva et al. (2015), studying cucumber and pepper seeds, respectively. Furthermore, it was found that the $\alpha$ coefficient decreased with increasing temperature and that the $\beta$ coefficient increased with increasing temperature (Figure 5b). Both showed linear adjustment with a high coefficient of determination, making it possible to determine the Gibbs free energy for any temperature, within the studied range. 
a.

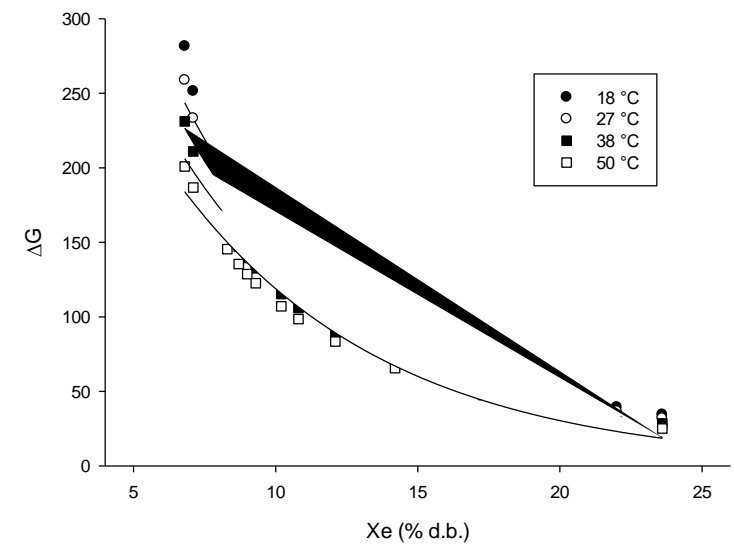

b.

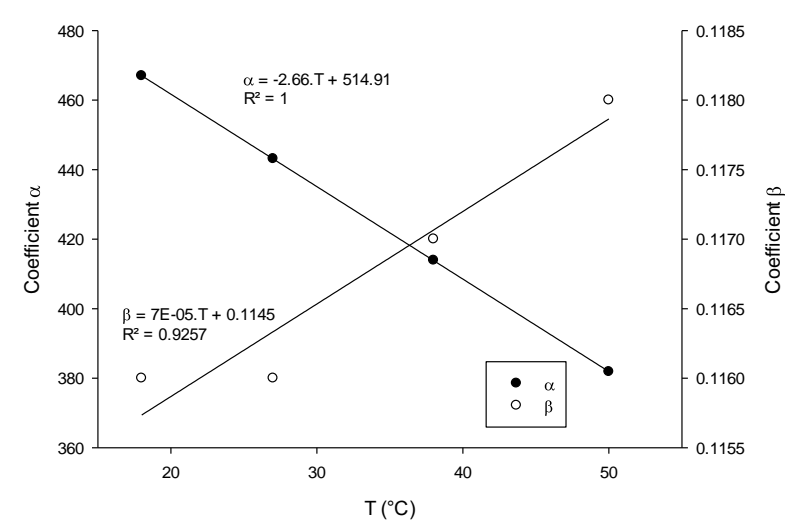

FIGURE 5. Gibbs free energy, as a function of water content (a); correlation between $\alpha$ and $\beta$ coefficients, derived from the equations that represent Gibbs free energy of white bean grains.

Nkolo Meze'e et al. (2008) report that Gibbs free energy is related to the work required to make sorption sites available. Positive Gibbs free energy values are characteristic of an exogenous reaction, that is, one that requires an external agent supplying energy to the environment. These positive values were already expected, since desorption is a non-spontaneous process, as observed in the present work, for white bean grains.

\section{CONCLUSIONS}

The mathematical model that best suited the experimental data representing the hygroscopic equilibrium curves of white bean grains was that of Sigma-Copace. The integral isosteric heat of desorption and the differential entropy increased as the water content decreased. The enthalpy-entropy compensation theory was valid for the phenomenon of water desorption of white bean grains, and this phenomenon was controlled by enthalpy.

Gibbs free energy was positive for the temperatures studied and increased throughout the desorption process. The positive values of Gibbs free energy characterized an exogenous reaction; therefore, the phenomenon of water desorption of white bean grains is not spontaneous.

\section{ACKNOWLEDGMENTS}

This study was financed in part by the Coordenação de Aperfeiçoamento de Pessoal de Nível Superior - Brasil (CAPES) - Finance Code 001

\section{REFERENCES}

Al-Muhtaseb A, McMinn WA, Magee TR (2004) Water sorption isotherms of starch powders. Part 2: thermodynamic characteristics. Journal of Food Engineering 62(2):135-142. DOI: http://dx.doi.org/10.1016/S0260-8774(03)00202-4.

Andrade ET, Correa PC, Teixeira LP, Pereira RG, Calomeni J (2010) Cinética de secagem e qualidade de sementes de feijão. Engevista 8(2):83-95. DOI: http://dx.doi.org/10.22409/engevista.v8i2.195.

Barros M, Prudencio SH (2016) Physical and chemical characteristics of common bean varieties. Semina: Ciências Agrárias 37(2):751-761. DOI: http://dx.doi.org/10.5433/1679-0359.2016v37n2p751.
Beristain CI, Garcia HS, Azuara E (1996) EnthalpyEntropy compensation in food vapor adsorption. Journal of Food Engineering 30(3-4):405-415. DOI: http://dx.doi.org/10.1016/S0260-8774(96)00011-8.

Brasil. Ministério da Agricultura e Reforma Agrária (2009) Regras para análises de sementes. Brasília, Secretaria Nacional de Defesa Agropecuária, 399p.

Brigide P, Canniatt-Brazaca SG, Silva MO (2014) Nutritional characteristics of biofortified common beans. Food Science and Technology 34(3):493-500. DOI: http://dx.doi.org/10.1590/1678-457x.6245.

Brooker DB, Bakker-Arkema FW, Hall CW (1992) Drying and storage of grains and oilseeds. New York, Springer, 450p.

Cavalcanti ASRRM, Rosa MERC (2016) Isotermas de dessorção de sementes de feijão branco. Revista Brasileira de Produtos Agroindustriais 18:431-542.

Cavalcanti ASRRM, Rosa MERC, Duarte MEM (2018) Propriedades termodinâmicas das sementes de feijão branco com base nas isotermas de equilíbrio higroscópico. Revista Brasileira de Produtos Agroindustriais 20(3):239-246.

CONAB - Companhia Nacional de Abastecimento (2019) $12^{\circ}$ levantamento da safra 2018/19. Acompanhamento da safra brasileira de grãos. 6(12):1-47.

Corrêa PC, Baptestini FM, Vanegas JDB, Leite R, Botelho FM, Oliveira GHH (2017) Kinetics of water sorption of damaged bean grains: thermodynamic properties. Revista Brasileira de Engenharia Agrícola e Ambiental 21(8):556561. DOI: https://doi.org/10.1590/1807-

1929/agriambi.v21n8p556-561

Corrêa PC, Botelho FM, Botelho SCC, Goneli ALD (2014) Isotermas de sorção de água de frutos de Coffea canephora. Revista Brasileira de Engenharia Agrícola e Ambiental 18(10):1047-1052. DOI: http://dx.doi.org/10.1590/18071929/agriambi.v18n10p1047-1052.

Corrêa PC, Oliveira GHH, Botelho FM, Goneli ALD, Carvalho FM (2010) Modelagem matemática e determinação das propriedades termodinâmicas do café (Coffea arabica L.) durante o processo de secagem. Revista Ceres 57(5):595-601. DOI: http://dx.doi.org/10.1590/S0034-737X2010000500005. 
Corrêa PC, Oliveira GHH, Botelho FM, Treto PC, Alves EA (2015a) Propriedades físicas e químicas interferentes na pós-colheita de café. Café na Amazônia, Embrapa Rondônia, p. 399-424.

Corrêa PC, Oliveira GHH de, Oliveira APLR de, VargasElías GA, Baptestini FM (2016) Particle size and roasting on water sorption in conilon coffee during storage. Coffee Science 11(2).

Corrêa PC, Reis MFT, Oliveira GHH de, Oliveira APLR de, Botelho FM (2015b) Moisture desorption isotherms of cucumber seeds: modeling and thermodynamic properties. Journal of Seed Science 37(3):218-225. DOI: http://dx.doi.org/10.1590/2317-1545v37n3149549.

Costa CF, Corrêa PC, Vanegas JDB, Baptestini FM, Campos RC, Fernandes LS (2016) Mathematical modeling and determination of thermodynamic properties of jabuticaba peel during the drying process. Revista Brasileira de Engenharia Agrícola e Ambiental 20(6):576580. DOI: http://dx.doi.org/10.1590/18071929/agriambi.v20n6p576-580.

Costa LM, Resende O, Oliveira DEC (2015) Determinação das isotermas de equilíbrio higroscópico de frutos de crambe pelo método dinâmico. Bioscience Journal 31(2):382-391. DOI: http://dx.doi.org/10.14393/BJv31n2a2015-22337.

Goneli ALD, Correa PC, Oliveira GHH de, Botelho FM (2010) Water desorption and thermodynamic properties of okra seeds. Transactions of the ASABE 53(1):191-197.

Hassini L, Bettaieb E, Desmorieux H, Torres SS, Touil A (2015) Desorption isotherms and thermodynamic properties of prickly pear seeds. Industrial Crops and Products 67:457-465. DOI:

http://dx.doi.org/10.1016/j.indcrop.2015.01.078.

Iglesias HA, Chirife J (1976) Prediction of the effect of temperature on water sorption isotherms of food material. International Journal of Food Science \& Technology 11(2):109-116. DOI: http://dx.doi.org/10.1111/j.13652621.1976.tb00707.x.

Kashaninejad M, Mortazavi A, Safekordi A, Tabil LG (2007) Thin-layer drying characteristics and modeling of pistachio nuts. Journal of Food Engineering 78(1):98-108. DOI: http://dx.doi.org/10.1016/j.jfoodeng.2005.09.007.

Krug RR, Hunter WG, Grieger RA (1976a) Enthalpyentropy compensation. 1. Some fundamental statistical problems associated with the analysis of van't hoff and arrhenius data. Journal of Physical Chemistry 80(21):2335-2341. DOI: http://dx.doi.org/10.1021/j100562a006.

Krug RR, Hunter WG, Grieger RA (1976b) Enthalpyentropy compensation. 2. Separation of the chemical from the statistical effect. Journal of Physical Chemistry 80(21):2341-2351. DOI: http://dx.doi.org/10.1021/j100562a007.

Kurozawa LE, de Oliveira RA, Hubinger MD, Park KJ (2015) Thermodynamic properties of water desorption of papaya. Journal of Food Processing and Preservation 39(6):2412-2420. DOI: http://dx.doi.org/10.1111/jfpp.12491.
Morais SJ da S, Devilla IA, Ferreira DA, Teixeira IR (2013) Modelagem matemática das curvas de secagem e coeficiente de difusão de grãos de feijão-caupi (Vigna unguiculata (L.) Walp.). Revista Ciência Agronômica 44(3):455-463. DOI: http://dx.doi.org/10.1590/S180666902013000300006 .

Nkolo Meze'e YN, Noah Ngamveng J, Bardet S (2008) Effect of enthalpy-entropy compensation during sorption of water vapour in tropical woods: The case of Bubinga (Guibourtia Tessmanii J. Léonard; G. Pellegriniana J.L.). Thermochimica Acta 468(1-2):1-5. DOI: http://dx.doi.org/10.1016/j.tca.2007.11.002.

Oliveira DEC, Resende O, Smaniotto TAS, Sousa KA, Campos RC (2013) Propriedades termodinâmicas de grãos de milho para diferentes teores de água de equilíbrio [Thermodynamic properties of maize grains for different equilibrium moisture contents]. Pesquisa Agropecuária Tropical 43(1): 50-56. DOI:

https://doi.org/10.4025/actasciagron.v39i3.32516

Oliveira DEC, Resende O, Chaves TH, Souza KA, Smaniotto TAS (2014) Propriedades termodinâmicas das sementes de pinhão-manso. Bioscience Journal 30(3):147-157.

Oliveira DEC, Resende O, Costa LM, Silva HW (2017) Thermodymnamic properties of crambe fruits. Acta Scientiarum. Agronomy 39(3):291-298. DOI: http://dx.doi.org/10.4025/actasciagron.v39i3.32516.

Palipane KB, Driscoll RH (1993) Moisture sorption characteristics of in-shell macadamia nuts. Journal of Food Engineering 18(1):63-76. DOI:

http://dx.doi.org/10.1016/0260-8774(93)90075-U.

Radünz LL, Melo E., Rocha RP, Barbosa FF, Santos RHS, Berbet P. (2014) Avaliação das curvas de secagem de guaco (Mikania glomerata Spreng.) em secador de bandejas. Revista Brasileira de Plantas Medicinais 16(2-1):378-387. DOI: http://dx.doi.org/10.1590/1983-084X/10_128.

Rizvi S (2014) Thermodynamic properties of foods in dehydration. Engineering Properties of Foods, CRC Press, 4 ed: p. 359-436. DOI: http://dx.doi.org/10.1201/b16897-12.

Ryde U (2014) A fundamental view of enthalpy-entropy compensation. MedChemCommun 5(9):1324-1336. DOI: http://dx.doi.org/10.1039/C4MD00057A.

Silva HW da, Costa LM, Resende O, Oliveira DEC de, Soares RS, Vale LSR (2015) Thermodynamic properties of pepper seeds - variety 'cabacinha'. Científica 44(1):14. DOI: http://dx.doi.org/10.15361/19845529.2016v44n1p14-22.

Teixeira LP, Andrade ET de, Devilla IA (2018) Isosteric heat, entropy, and Gibbs free energy of pumpkin seeds (Cucurbita moschata). Engenharia Agrícola 38(1):97-102. DOI: http://dx.doi.org/10.1590/1809-4430eng.agric.v38n1p97-102/2018.

Wang N, Brennan JG (1991) Moisture sorption isotherm characteristics of potatoes at four temperatures. Journal of Food Engineering 14(4):269-287. DOI: http://dx.doi.org/10.1016/0260-8774(91)90018-N. 